\title{
Nutrient-hormone signals regulating muscle protein turnover in pigs
}

\author{
BY BERNARD SÈVE ${ }^{1}$ AND ANDREW A. PONTER ${ }^{2}$ \\ ${ }^{1}$ Institut National de la Recherche Agronomique, Station de Recherches Porcines, \\ 35590 Saint-Gilles, France \\ ${ }^{2}$ Ecole Nationale Vétérinaire d'Alfort, Laboratoire d'Epidémiologie et de Gestion de la Santé \\ Animale, 94704 Maisons Alfort, France
}

In economic terms, muscle is the most important tissue for pig producers. Research has been largely focused, therefore, on the means by which to increase carcass muscle content, as well as the efficiency of nutrient use for muscle growth. Since a major component in this tissue is protein, the rate at which protein is continuously synthesized and degraded, i.e. the rate of protein turnover, is related to growth and, particularly, to feed efficiency for growth. Thus, protein turnover is of nutritional importance. Furthermore, turnover is primarily dependent on intrinsic factors such as age, sex or genotype, which are generally related to a specific hormone status. However, most of the time, these intrinsic factors interact with nutrients either through stimulation of hormone secretion or production in an endocrine, or autocrine or paracrine way, and/or through action at the receptor level. The present paper describes some of the nutrient-hormone signals involved in the regulation of muscle protein turnover in pigs.

\section{THE NUTRITIONAL IMPORTANCE OF MUSCLE PROTEIN TURNOVER IN PIGS}

The first nutritional impact of protein turnover is on energy requirement. In pigs, results of experiments published at the beginning of the $1980 \mathrm{~s}$ can be used to estimate the proportion of heat production attributable to whole-body protein synthesis in a $35 \mathrm{~kg}$ growing pig. The estimate given by Reeds \& Fuller (1983) was $20 \%$ on the basis of an energy cost of $5.32 \mathrm{~kJ} / \mathrm{g}$ protein synthesized (Reeds et al. 1981), with a marginal increase in protein synthesis rate of $2.2 \mathrm{~g} / \mathrm{g}$ deposited protein (Reeds et al. 1980). The minimal value calculated for the energy cost of protein synthesis using the stoichiometric approach is $3.56 \mathrm{~kJ} / \mathrm{g}$ (Waterlow et al. 1978). The difference between the theoretical and measured value was explained by auxiliary energy expenditure (Reeds et al. 1985). Indeed, $\mathrm{Na}^{+}, \mathrm{K}^{+}-$ ATPase (EC 3.6.1.3)-dependent respiration was shown to be closely associated with protein synthesis rates in pig muscles (Adeola et al. 1989). However, even with the stoichiometric approach, the range of the estimates may be $3 \cdot 0-7.3 \mathrm{~kJ} / \mathrm{g}$ depending on the assumptions used (Aoyagi et al. 1988). On the basis of more recent energy metabolism studies giving a marginal cost for fat deposition of $9.7 \mathrm{~kJ} / \mathrm{g}$ (efficiency of energy for fat accretion 0.80 ) and a marginal cost for protein deposition of $15.9 \mathrm{~kJ} / \mathrm{g}$ (efficiency of energy for protein accretion 0.60 ) according to Noblet et al. (1989), the highest value $(7.3 \mathrm{~kJ} / \mathrm{g}$ synthesized protein) can also be estimated using the measurements of Reeds et al. (1980) in pigs. It would enable the cost of additional protein synthesis associated with protein deposition to match the cost of protein deposition. That would provide an estimate of $30 \%$ of total heat production associated with protein synthesis in a $35 \mathrm{~kg}$ pig, bearing in mind that about half this amount is part of the energy requirement for maintenance (Fig. 1).

As far as muscle is concerned, it must be stated that due to its slow rate of protein turnover compared with liver and gastrointestinal tract, it was calculated that, while it may represent more than $50 \%$ of whole-body protein, muscle will represent only $35 \%$ of 


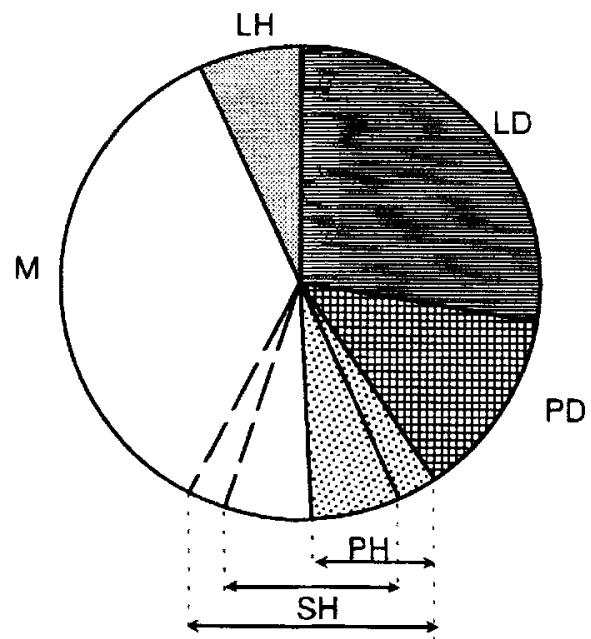

Fig. 1. Partition of metabolizable energy in a $35 \mathrm{~kg}$ pig growing at an average daily gain of $700 \mathrm{~g} / \mathrm{d}$. M, Maintenance heat; LD, energy of deposited lipid; LH, heat associated with lipid deposition; PD, energy of deposited protein; PH, heat associated with protein deposition; $\mathrm{SH}$, heat associated with protein synthesis, $20-30 \%$ of total heat production (After Reeds et al. 1980, 1981).

whole-body protein synthesis (Fig. 2). Therefore, muscle protein turnover itself would represent only about $10 \%$ of total heat production, i.e. about $6 \%$ the energy requirement of the previously described pig. The impact of protein turnover on protein or amino acid efficiency is still a debated matter. The fact that maximal $\mathrm{N}$ or amino acid efficiency is relatively constant and independent of intrinsic factors would suggest only a marginal effect on efficiency. However, the increase in whole-body protein degradation is generally accompanied by an expansion of the free amino acid pool which may proportionally increase the rate of amino acid oxidation. In this case, amino acid mobilization from muscle in the post-absorptive state, following excessive acceleration of synthesis in the fed state, for example, would result in decreased amino acid efficiency. Such a phenomenon is very likely in fast-growing pigs approaching maximal growth, based on a curvilinear response to nutrient supply (Fuller \& Garthwaite, 1993; Gahl et al. 1994).

(a) Whole-body protein

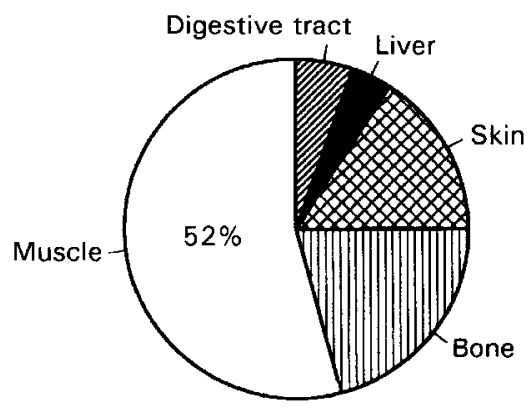

(b) Whole-body protein synthesis

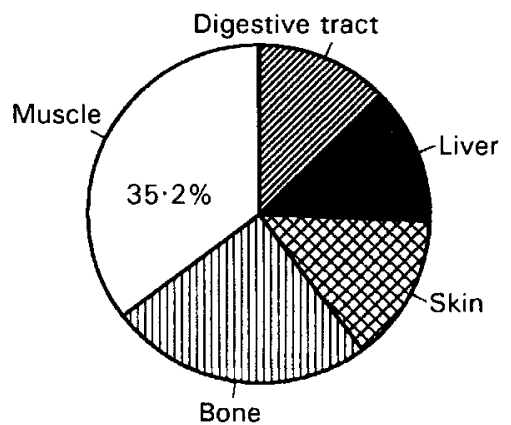

Fig. 2. Relative importance of muscle protein synthesis (b) compared with the relative importance of muscle in the body (without thoracic organs; a) of suckled piglets (From Sève \& Ballèvre, 1991). 


\section{THE EFFECT OF FASTING AND RE-FEEDING ON MUSCLE PROTEIN TURNOVER IN LABORATORY ANIMALS}

Most relevant data on the effect of fasting and re-feeding on protein turnover were obtained with measurements of muscle protein synthesis rates using the flooding-dose technique (Garlick et al. 1980). In a classic paper, Garlick et al. (1983) showed that insulin infusion could simulate the effect of re-feeding on muscle protein fractional synthesis rate (FSR) in post-absorptive rats. Later, Preedy \& Garlick (1986) using an anti-insulin serum demonstrated that the physiological level of insulin obtained in response to glucose infusion was required to increase muscle FSR. By contrast, the evidence in human subjects and adult animals, using the tracer amino acid infusion technique, was that insulin induced a decrease in whole-body protein degradation rather than an increase in protein synthesis rate (Grizard et al. 1995). Indeed, it was shown later that protein synthesis was influenced only to a small extent by insulin infusion in adult rats (Baillie \& Garlick, 1991a). Furthermore, oxidative muscles were shown to be much less sensitive to insulin than glycolytic muscles (Baillie \& Garlick, 1991b). The length of the period of fasting was also apparently responsible for reducing muscle protein synthesis sensitivity to insulin. In fact, since the major effect of fasting was a loss of RNA, there was an increase in protein synthesis rate per unit RNA $\left(K_{R N A}\right)$. This was a first indication that RNA activity, i.e. initiation or translation rate, was the main target for insulin action.

Recently, it was shown in adult mice that muscle protein synthesis did not respond to insulin, although a clear response was recorded to re-feeding after fasting. Parallel to this, an anti-insulin-like growth factor (IGF)-1 serum was more effective in depressing refeeding-induced protein synthesis than an anti-insulin serum (Svansberg et al. 1996). Since the anti-insulin effect was still significant, the conclusion from this work seems to be that both insulin and IGF-1 are significant permissive factors in the stimulation of protein synthesis associated with re-feeding. On the other hand, there was no acute response of plasma IGF-1 to re-feeding, but IGF-1 gene was shown to be rapidly expressed in the muscle, suggesting an autocrine or paracrine action. The importance of insulin was confirmed on an interesting adult rat model of exercise-induced muscle hypertrophy clearly involving stimulation of protein synthesis (Fluckey et al. 1996). Within the same rat, using a bilateral hindlimb preparation, it was shown that insulin activated muscle protein synthesis rate under the condition that this rat was previously exercised. Furthermore, this effect was restricted to muscles involved in the exercise regardless of their contractile or metabolic characteristics. Indeed, in the fast-twitch muscle of exercised rats, 'insulin deficiency' resulted in lower protein synthesis rate associated with an accumulation of RNA. Therefore, it was confirmed that the effect of insulin was on RNA activity. Conversely, the increase in muscle RNA content, which may be important for further enhancement of hypertrophy through protein synthesis, would be clearly independent of insulin.

\section{THE EFFECT OF FASTING AND RE-FEEDING ON MUSCLE PROTEIN TURNOVER IN PIGS}

First, it was clear from a classic experiment by Fuller et al. (1977) that the anabolic role of nutrients, particularly carbohydrate, was closely related to insulin. With continuous infusion of a tracer amino acid, in $16 \mathrm{~h}$-fasted $35 \mathrm{~kg}$ pigs, it was shown that an additional $3 \mathrm{~h}$ of fasting ( $19 \mathrm{~h}$ in all) decreased both whole-body protein degradation and protein synthesis, i.e. protein turnover (Ostaszewski \& Nissen, 1988). The major re-feeding effect was a decrease in protein degradation rate while protein synthesis rate was re-established at 
the $16 \mathrm{~h}$ fasting level, consistent with an anabolic action of insulin through inhibition of proteolysis.

We compared the effect of fasting on protein synthesis rates in different tissues of three different genotypes of 3-week-old suckling pigs using the flooding-dose technique (E. Caparo and B. Sève, unpublished results). The superiority of the Piétrain pigs in terms of muscle growth rate was reflected only in a higher muscle RNA : protein value compared with the other two genotypes which were not different (Table 1). Indeed, there was a linear decrease in muscle protein FSR relative to the time interval after the last meal. Comparison with the liver and intestine suggested that muscle was more sensitive to fasting than the other tissues. Since RNA content did not change, this effect was totally explained by RNA activity and paralleled the decrease in plasma insulin. The pigs most sensitive to fasting were Large White, followed by Piétrain, and the least sensitive pigs were the Chinese MeiShan. Between-genotype differences in sensitivity to fasting were approximately related to the rates of decrease in plasma insulin concentrations. Furthermore, with fasting, plasma cortisol increased less rapidly in Mei-Shan and Piétrain pigs than in Large White pigs, from a higher fed state value in Mei-Shan and from a similar value in Piétrain pigs. Conversely, plasma IGF-1 decreased less rapidly in Mei-Shan and Piétrain pigs than in Large White pigs from a similar fed-state value in Mei-Shan and from a lower value in Piétrain pigs. However, it was clear that the mean absolute values of plasma cortisol or IGF-1 concentrations did not explain between-genotype differences. For example, Piétrain pigs had the lowest plasma IGF-1 concentrations and the highest muscle protein synthesis rate. Interestingly, it was also the only group in which plasma IGF-1 was significantly correlated with muscle RNA activity (Fig. 3). Nevertheless, although re-feeding data were not available, these results strongly suggest that fasting-re-feeding-associated variations in muscle protein synthesis are determined by insulin and modulated by other hormones in a breed-specific way.

An essential role for insulin in the response of muscle protein synthesis to re-feeding after fasting ( $24 \mathrm{~h})$ was recently confirmed and claimed to be age-dependent in suckling piglets (Davis et al. 1996). Indeed, in absolute terms, muscle protein FSR and RNA activity were increased by re-feeding, to a greater extent in 7-d-old pigs than in 26-d-old pigs,

Table 1. Effect of fasting on longissimus dorsi muscle protein synthesis rate and plasma hormone concentrations in different genotypes of 3-week-old suckling pigs (From E. Caparo and B. Sève, unpublished results)

\begin{tabular}{|c|c|c|c|c|c|c|}
\hline Genotype & $\begin{array}{c}K s \\
(\% / \mathrm{d})\end{array}$ & $\begin{array}{l}\text { RNA : protein } \\
\text { (mg/g) }\end{array}$ & $\begin{array}{c}K_{R N A} \\
(\mathrm{mg} / \mathrm{mg})\end{array}$ & $\begin{array}{l}\text { Insulin } \\
(\mathrm{mU} / \mathrm{l})\end{array}$ & $\begin{array}{l}\text { Cortisol } \\
\text { (ng/ml) }\end{array}$ & $\begin{array}{l}\text { IGF-1 } \\
(\mathrm{ng} / \mathrm{ml})\end{array}$ \\
\hline \multicolumn{7}{|l|}{ Large White } \\
\hline Fed & 11.5 & 6.7 & 17.2 & $12 \cdot 1$ & 62 & 280 \\
\hline $6 \mathrm{~h}$ fast & 7.9 & 6.9 & 11.5 & $4 \cdot 1$ & 91 & 220 \\
\hline $12 \mathrm{~h}$ fast & 5.6 & $6 \cdot 6$ & $8 \cdot 3$ & $4 \cdot 1$ & 112 & 173 \\
\hline \multicolumn{7}{|l|}{ Piétrain } \\
\hline Fed & 11.4 & 7.5 & $15 \cdot 4$ & 3.2 & 76 & 169 \\
\hline $6 \mathrm{~h}$ fast & 9.6 & 7.8 & 12.6 & 1.4 & 98 & 127 \\
\hline $12 \mathrm{~h}$ fast & 7.8 & 7.6 & $10 \cdot 0$ & 2.6 & 85 & 137 \\
\hline \multicolumn{7}{|l|}{ Mei-Shan } \\
\hline Fed & $10 \cdot 1$ & 7.0 & $14 \cdot 6$ & $6 \cdot 3$ & 102 & 264 \\
\hline $6 \mathrm{~h}$ fast & 8.2 & $7 \cdot 1$ & 11.8 & 2.8 & 106 & 311 \\
\hline $12 \mathrm{~h}$ fast & 7.7 & 6.7 & 11.7 & 2.8 & 131 & 211 \\
\hline
\end{tabular}

$K s$, protein fractional synthesis rate; $K_{R N A}$, protein synthesis rate per unit RNA; IGF-1, insulin-like growth factor-1. 


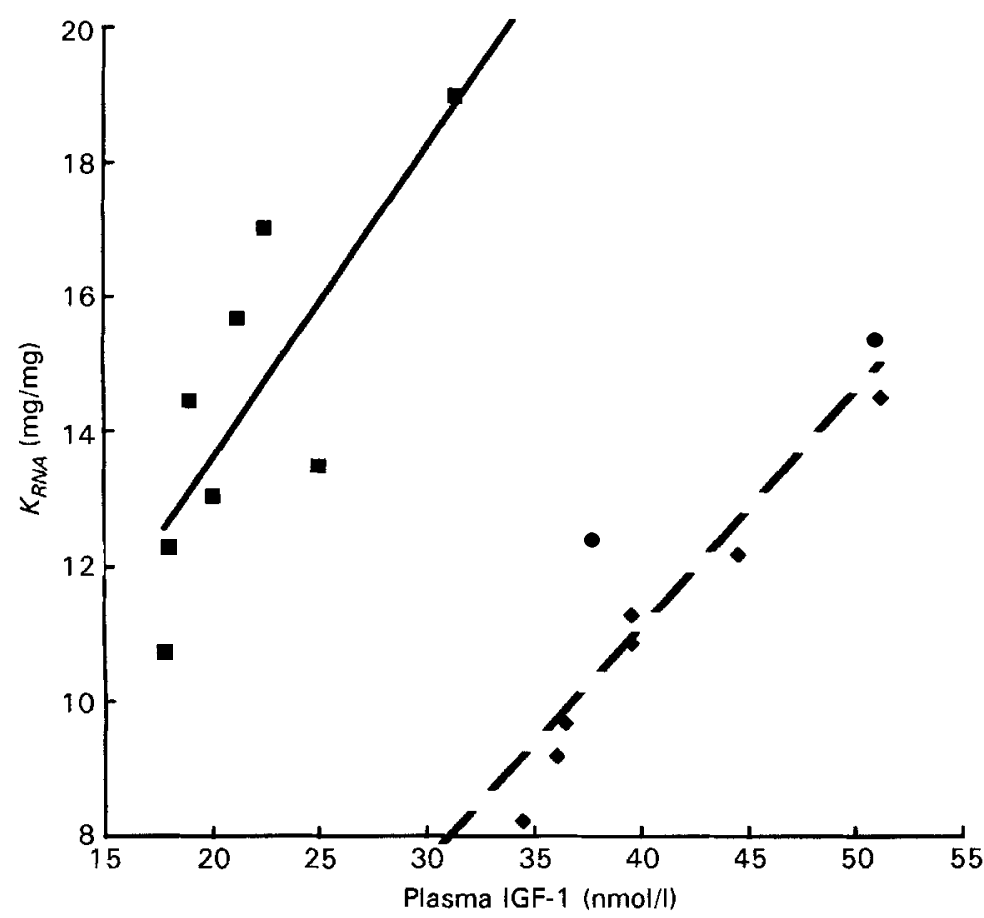

Fig. 3. Relationship between muscle protein synthesis per unit RNA $\left(K_{R N A}\right)$ and plasma insulin-like growth factor (IGF)-1 compared in $65 \mathrm{~kg}$ porcine growth hormone (GH)-treated Piétrain $\times$ Large-White pigs ( $\$$; Sève et al. 1993) and in $5 \mathrm{~kg}$ Piétrain piglets (G; E. Caparo and B. Sève, unpublished results). For GH-treated pigs: $y=0 \cdot 35 x+2 \cdot 85, R^{2}$ 0.86 ; for Piétrain pigs $y=0.46 x+4.30, R^{2} 0.62$.

although the effect was proportional regardless of age (Table 2). Furthermore, the classic developmental decrease in RNA : protein value was accompanied by a decrease in $K_{R N A}$, suggesting enhanced sensitivity of muscle protein synthesis to insulin in younger pigs. Because the acute plasma insulin response to re-feeding was significant and higher in younger pigs, although the age effect appeared only at the second meal, the authors postulated that insulin mediation of the re-feeding effect occurred both at the level of secretion and at the target organ level. They proposed hyperinsulinaemic euglycaemic euaminoacidaemic clamp studies to test this hypothesis. Since, by contrast, there were no acute increases in plasma IGF- 1 concentrations after the fasting-induced reduction, they

Table 2. Effect of re-feeding on muscle protein synthesis in suckling piglets according to age (From Davis et al. 1996)

\begin{tabular}{lccccccc}
\hline \hline Muscle ... & \multicolumn{3}{c}{ Longissimus dorsi } & & \multicolumn{2}{c}{ Heart } \\
\cline { 2 - 3 } \cline { 6 - 8 } Age (d) & $\begin{array}{c}K s \\
(\% / \mathrm{d})\end{array}$ & $\begin{array}{c}\text { RNA:protein } \\
(\mathrm{mg} / \mathrm{g})\end{array}$ & $\begin{array}{c}K_{R N A} \\
(\mathrm{mg} / \mathrm{mg})\end{array}$ & & $\begin{array}{c}K s \\
(\% / \mathrm{d})\end{array}$ & $\begin{array}{c}\text { RNA:protein } \\
(\mathrm{mg} / \mathrm{g})\end{array}$ & $\begin{array}{c}K_{R N A} \\
(\mathrm{mg} / \mathrm{mg})\end{array}$ \\
\hline 7: Fasting & 16.0 & 19.5 & 8.2 & & 14.4 & 21.5 & 6.7 \\
Refed & 25.9 & 19.8 & 13.1 & & 16.9 & 21.1 & 8.0 \\
26: Fasting & 4.0 & 8.8 & 4.6 & & 9.7 & 13.5 & 7.2 \\
Refed & 7.0 & 9.3 & 7.5 & & 10.8 & 15.0 & 7.2 \\
\hline \hline
\end{tabular}

$K s$, protein fractional synthesis rate; $K_{R N A}$, protein synthesis rate per unit RNA. 
rejected the hypothesis of a role for IGF-1 in the muscle protein synthesis response to refeeding. However, more information is needed on both IGF-1 muscle gene expression (Svansberg et al. 1996) and plasma cortisol variations, as suggested in the previously reviewed data.

\section{THE EFFECT OF WEANING AND NON-PROTEIN DIETARY ENERGY ON MUSCLE PROTEIN TURNOVER IN PIGS}

Weaning involves a period of fasting and undernutrition associated with profound changes in the nature of nutrients. On the first week after weaning, the main consequence is a suppression of growth, affecting RNA and protein content to the same extent since the RNA : protein is unchanged. Compared with heavier suckled pigs of the same age, the apparent loss of RNA is probably the main handicap caused by undernutrition. This resulted in only a slight decrease in muscle protein FSR and $K_{R N A}$ (Sève et al. 1987), although total synthesis rate was undoubtedly affected in proportion to growth retardation. Comparison made on littermates observed either at weaning or 1 week later (Sève et al. 1986) even suggested that, despite undernutrition, weaning could reverse the previously described developmental decline in $K_{R N A}$ when dietary protein supply was adequately increased (Table 3 ). This raises the question: is muscle RNA activity still insulin-dependent in this particular circumstance?

In fact, at weaning there is a major change in the nature of non-protein energy from fat to carbohydrate. In older growing pigs, the anabolic effects of dietary fat or carbohydrates were shown to be obtained with hardly measurable effects on protein turnover as opposed

Table 3. Effect of weaning and dietary protein on longissimus muscle protein synthesis rate in pigs (From Sève et al. 1986)

\begin{tabular}{|c|c|c|c|}
\hline \multirow{2}{*}{$\begin{array}{l}\text { Period... } \\
\text { Dietary protein }(\mathrm{g} / \mathrm{kg}) \ldots\end{array}$} & \multirow{2}{*}{$\begin{array}{l}\text { Before weaning } \\
\quad \text { (milk) }\end{array}$} & \multicolumn{2}{|c|}{1 week after weaning } \\
\hline & & 150 & 300 \\
\hline$K s(\% / \mathrm{d})$ & $18 \cdot 2^{\mathrm{a}}$ & $13.9^{\mathrm{b}}$ & $17 \cdot 4^{\mathrm{a}}$ \\
\hline RNA : protein $(\mathrm{mg} / \mathrm{g})$ & $13.7^{\mathrm{a}}$ & $10.4^{\mathrm{b}}$ & $9.5^{b}$ \\
\hline$K_{R N A}(\mathrm{mg} / \mathrm{mg})$ & $13.5^{\mathrm{a}}$ & $14 \cdot 7^{\mathrm{a}}$ & $18.4^{\mathrm{b}}$ \\
\hline
\end{tabular}

${ }^{\mathrm{a}, \mathrm{b}}$ Means in the same horizontal row with unlike superscript letters were significantly different $(P<0.05)$.

$K s$, protein fractional synthesis rate; $K_{R N A}$, protein synthesis rate per unit RNA.

Table 4. Effect of dietary energy source (carbohydrate v. fat) using regimens which were isoenergetic and had the same protein:energy value in tube-fed newly-weaned piglets on plasma insulin (0-120 min) and longissimus muscle protein synthesis rate (From Ponter et al. 1994a)

\begin{tabular}{lcc}
\hline \hline Non-protein energy source ... & Carbohydrate & Fat \\
\hline Plasma insulin (mU/) & $159^{\mathrm{b}}$ & $96^{\mathrm{a}}$ \\
$K s(\% / \mathrm{d})$ & $9 \cdot 0^{\mathrm{a}}$ & $8 \cdot 7^{\mathrm{a}}$ \\
RNA : protein (mg/g) & $7 \cdot 8^{\mathrm{a}}$ & $7 \cdot 3^{\mathrm{a}}$ \\
$K_{R N A}(\mathrm{mg} / \mathrm{mg})$ & $11 \cdot 7^{\mathrm{a}}$ & $11 \cdot 8^{\mathrm{a}}$ \\
\hline
\end{tabular}

${ }^{a, b}$ Means in the same horizontal row with unlike superscript letters were significantly different $(P<0.05)$.

$K s$, protein fractional synthesis rate; $K_{R N A}$, protein synthesis rate per unit RNA. 
to the very important effects of protein (Reeds et al. 1981). We compared carbohydrate and fat in diets for newly early-weaned piglets (Ponter et al. 1994b). There was no significant difference in either muscle RNA : protein or RNA activity between piglets fed on the same amounts of balanced protein and non-protein energy, whether in the form of fat or in the form of carbohydrate (Table 4). This result was obtained despite a much lower response in plasma insulin to the fat-rich meal than to the carbohydrate-rich meal, and illustrates the fact that in piglets, as in rats (Jepson et al. 1988), the role of insulin in protein synthesis is probably a permissive one within quite a low range of plasma concentrations. However, the interaction with dietary protein or amino acids remained to be considered.

\section{THE EFFECT OF DIETARY PROTEIN OR AMINO ACIDS ON MUSCLE PROTEIN TURNOVER IN PIGS}

The most relevant experiments showing the effect of protein and amino acids on muscle protein synthesis in rats are from Garlick's group. Simultaneous infusion of a mixture of amino acids with insulin stimulated the response of muscle FSR within a low range of plasma concentration (0-20 mU/1; Garlick \& Grant, 1988). The other classic results were, first, that essential rather than non-essential amino acids were involved and, second, that branched-chain amino acids could reproduce the effect of the essential amino acids. Again, some controversy came from studies in mature rats and human subjects (Bennet et al. 1990) showing that an increase in aminoacidaemia, per se, could be responsible for the stimulation of muscle protein synthesis. However, in this study, increased levels of plasma hormones were shown in response to the infused amino acids. This was the starting point for an experiment on hindlimb-infused pigs in which plasma hormone levels were strictly controlled. It was very clear from these studies that hyperaminoacidaemia without hyperinsulinaemia or hyperglucagonaemia strongly stimulated protein synthesis rate in pig hindlimb muscles (Watt et al. 1992; Table 5). Nevertheless, these results were still consistent with the view that amino acids enhanced the sensitivity of muscle protein synthesis to insulin, as proposed by Garlick \& Grant (1988).

The previously mentioned data corroborated the results of experiments testing the effect of an increase in dietary protein on whole-body protein synthesis in pigs (Reeds et al. 1981). They were particularly interesting when considering our data on weaned piglets. The fact that the decrease in FSR, which is normally associated with a decrease in RNA : protein, was prevented by increasing dietary protein supply could be the consequence of a higher tissue sensitivity to insulin which stimulated RNA activity after weaning (Sève et al. 1986). This would imply that, in weanling pigs, there is not sufficient

Table 5. Effect of the infusion of amino acids at constant insulin availability in the systemic blood on plasma hormones and protein synthesis rate in the hindlimb of growing pigs (From Watt et al. 1992)

\begin{tabular}{lcc}
\hline \hline Infusion ... & Control & Amino acids \\
\hline At 240 min in plasma: & 19.3 & 18.9 \\
Insulin (mU/) & 356 & 362 \\
Glucagon $(\mathrm{pg} / \mathrm{ml})$ & $73^{\mathrm{a}}$ & $229^{\mathrm{b}}$ \\
$\alpha-\mathrm{NH}_{2}-\mathrm{N}(\mathrm{mg} / \mathrm{l})$ & $3 \cdot 3$ & $3 \cdot 1$ \\
Glucose $(\mathrm{mmol} / \mathrm{l})$ & $0.041^{\mathrm{a}}$ & $0.079^{\mathrm{b}}$ \\
Protein synthesis at $180-240$ min in the hindlimb $(\% / \mathrm{h})$ & & \\
\hline \hline
\end{tabular}

${ }^{\mathrm{a}, \mathrm{b}}$ Means in the same horizontal row with unlike superscript letters were significantly different $(P<0.002)$. 
Table 6. Nutrient-independent stimulation of protein synthesis in muscles of colostrum-fed newborn pigs (From Burrin et al. 1995)

\begin{tabular}{lccc}
\hline \hline Feed ... & Mature milk & Colostrum & Iso-protein formula* \\
\hline Ks $(\% / \mathrm{d})$ after 24h: & $77 \cdot 0^{\mathrm{b}}$ & $93 \cdot 4^{\mathrm{c}}$ & $98 \cdot 7^{\mathrm{c}}$ \\
Liver & $24 \cdot 8^{\mathrm{b}}$ & $32 \cdot 7^{\mathrm{c}}$ & $22 \cdot 5^{\mathrm{b}}$ \\
Longissimus muscle & $25 \cdot 1^{\mathrm{b}}$ & $35 \cdot 5^{\mathrm{c}}$ & $25 \cdot 9^{\mathrm{b}}$ \\
Gastrocnemius muscle & $1.08^{\mathrm{a}}$ & $2 \cdot 71^{\mathrm{b}}$ & $3 \cdot 90^{\mathrm{c}}$ \\
Plasma variation (mmol// per 12 h): & $0 \cdot 17^{\mathrm{a}}$ & $0 \cdot 56^{\mathrm{b}}$ & $0 \cdot 85^{\mathrm{c}}$ \\
Total amino acids & \\
Branched-chain amino acids &
\end{tabular}

${ }^{a, b, c}$ Means in the same horizontal row with unlike superscript letters were significantly different $(P<0-05)$.

$K s$, protein fractional synthesis rate.

* Formula simulating the composition of colostrum, mainly in relation to its higher protein content than milk.

time for the adaptation to protein deficiency to occur, as seen at the insulin or IGF-1 receptor level in growing rats (Grizard et al. 1995). Weaning is the second critical phase in the life of pigs after birth, but birth provides even less chance of an adaptation to the lack of nutrients. For this reason, it was interesting to investigate the $50 \%$ higher muscle protein synthesis rate induced by colostrum compared with milk (Burrin et al. 1992). However, a formula simulating the composition of colostrum, mainly its higher content of protein, did not reproduce the differential effect of colostrum compared with milk (Burrin et al. 1995; Table 6). The authors concluded that a nutrient-independent effect of colostrum was occurring, but rejected the implication of colostrum-borne insulin or IGF-1.

\section{THE INTERACTION OF DIETARY PROTEIN AND EXOGENOUS GROWTH HORMONE ON MUSCLE PROTEIN TURNOVER IN PIGS}

The effect of dietary protein on muscle FSR as well as total protein synthesis rates was also demonstrated in heavier pigs with and without daily injection of growth hormone (GH) (Sève et al. 1993). The response to $\mathrm{GH}$ was clearly significant and $\mathrm{GH}$ seemed to be synergistic with dietary protein, although the interaction did not reach significance (Table 7). In contrast, only the GH treatment increased the FSR of liver protein and there was no effect of either factor on digestive tissues. The efficiency of muscle protein synthesis to increase muscle protein deposition, estimated by fractional growth rate (FGR):FSR, was improved with the higher dietary protein intake, but remained constant with GH treatment.

Table 7. Effect of porcine growth hormone ( $p G H)$ treatment on longissimus muscle protein fractional synthesis $(\mathrm{Ks})$, degradation $(\mathrm{Kd})$ and growth $(\mathrm{Kg})$ rates $(\% / d)$, and efficiency of protein synthesis for growth (From Sève et al. 1993)

\begin{tabular}{llllll}
\hline \multirow{2}{*}{ Dietary protein $(\mathrm{g} / \mathrm{kg}) \ldots$} & \multicolumn{2}{c}{124} & & \multicolumn{2}{c}{208} \\
\cline { 2 - 3 } \cline { 5 - 6 } & 0 & 3 & & 0 & 3 \\
\hline$K s$ & $3 \cdot 24^{\mathrm{a}}$ & $3 \cdot 68^{\mathrm{a}, \mathrm{b}}$ & & $4 \cdot 14^{\mathrm{b}}$ & $5 \cdot 09^{\mathrm{c}}$ \\
$K d$ & $2 \cdot 31^{\mathrm{a}}$ & $2 \cdot 63^{\mathrm{a}, \mathrm{b}}$ & & $2 \cdot 73^{\mathrm{b}}$ & $3 \cdot 45^{\mathrm{c}}$ \\
$K g$ & $0.93^{\mathrm{a}}$ & $1 \cdot 05^{\mathrm{a}}$ & & $1.41^{\mathrm{b}}$ & $1 \cdot 64^{\mathrm{c}}$ \\
$K s: K g$ & $3 \cdot 51^{\mathrm{a}}$ & $3 \cdot 58^{\mathrm{a}}$ & & $2 \cdot 94^{\mathrm{b}}$ & $3 \cdot 11^{\mathrm{b}}$ \\
\hline
\end{tabular}

\footnotetext{
a,b,c Means for $K s, K d$ and $K g$ in the same horizontal row with unlike superscript letters were significantly different $(P<0.05)$; means for $K s: K g$ with unlike superscript letters were significantly different $(P<0.10)$.
} 
Therefore, together with the increase in liver FSR, the muscle FSR : FGR data suggest that the energy cost of protein deposition is higher when stimulated by GH than when enhanced by increasing dietary protein supply to the pig requirement. On the other hand, the efficiency of dietary protein for protein deposition was increased with $\mathrm{GH}$ treatment, while it was decreased with the additional dietary protein supply. This suggests that to improve protein retention the hormone and the nutrient both limit the increase in protein degradation commonly associated with an increase in protein synthesis, but act in very different ways. GH could act by providing energy through the diversion of energy nutrients from lipogenesis, i.e. through a re-partitioning process. As discussed previously, protein might operate on muscle by mass action of the whole free amino acid pool, or through an improvement in the sensitivity to insulin caused by specific amino acids. Speculating that two different mechanisms are involved in the respective effects of protein and $\mathrm{GH}$ is consistent with the fact that they are at least additive. The trend to a synergy could be understood as a result of the cooperative action of exogenous $\mathrm{GH}$ and dietary protein; $\mathrm{GH}$ elevating plasma insulin concentration and protein counteracting the $\mathrm{GH}$-induced insulin resistance at the muscle level.

In pigs, contrary to other species, the IGF-1 response was not significantly changed by dietary protein both in terms of plasma concentrations and in terms of liver or muscle gene transcription (Grant et al. 1990; Table 8). However, as in other species, the most significant effect of exogenous GH was shown to be an increase in plasma IGF-1 concentrations. This response was associated with increased IGF-1 gene transcription in the liver rather than in the muscle (Table 9). This leads to the hypothesis of a major role for endocrine IGF-1 in the response of pig muscle protein synthesis and deposition (anabolic response) to exogenous GH. Endocrine IGF-1 can be simulated by exogenous IGF-1 infusion. However,

Table 8. Effect of porcine growth hormone ( $p G H)$ treatment on plasma hormone concentrations (nmol/) (From Sève et al. 1993)

\begin{tabular}{llccccc}
\hline \hline \multirow{2}{*}{ Dietary protein $(\mathrm{g} / \mathrm{kg}) \ldots$} & \multicolumn{2}{c}{124} & & \multicolumn{2}{c}{208} \\
\cline { 2 - 4 } \cline { 5 - 6 } & 0 & 3 & & 0 & 3 \\
\hline pGH $(\mathrm{mg} / \mathrm{d}) \ldots$ & $19^{\mathrm{a}} \ldots$ & $38^{\mathrm{b}}$ & & $19^{\mathrm{a}}$ & $43^{\mathrm{b}}$ \\
IGF-1 & $39^{\mathrm{a}}$ & $29^{\mathrm{b}}$ & $38^{\mathrm{b}}$ & $32^{\mathrm{a}, \mathrm{b}}$ \\
T4 & 1.9 & 2.0 & 2.0 & 1.8 \\
\hline
\end{tabular}

${ }^{\mathrm{a}, \mathrm{b}}$ Means in the same horizontal row with unlike superscript letters were significantly different $(P<0.05)$. $\mathrm{IGF}-1$, insulin-like growth factor-1; T4, thyroxine; $\mathrm{T} 3$, triiodothyronine.

Table 9. Effect of porcine growth hormone $(p G H)$ treatment on the transcription of the insulin-like growth factor (IGF)-1 gene in the liver and in the longissimus muscle (IGF-1 $m R N A$ relative to a common control hybridization standard) (From Grant et al. 1991)

\begin{tabular}{|c|c|c|c|c|}
\hline \multirow{2}{*}{$\begin{array}{l}\text { Dietary protein }(\mathrm{g} / \mathrm{kg}) \ldots \\
\text { pGH treatment } \ldots\end{array}$} & \multicolumn{2}{|c|}{140} & \multicolumn{2}{|c|}{200} \\
\hline & - & + & - & + \\
\hline Liver & $0.215^{\mathrm{a}}$ & $0.582^{b}$ & $0.241^{\mathrm{a}}$ & $0.721^{b}$ \\
\hline Muscle & $0.304^{a}$ & $0.234^{\mathrm{a}}$ & $0.276^{a}$ & $0.230^{a}$ \\
\hline
\end{tabular}

\footnotetext{
a,b Means in the same horizontal row with unlike superscript letters were significantly different $(P<0 \cdot 05)$.

- , Without pGH; +, with pGH.
} 
it was shown recently in rats that such an infusion decreased plasma insulin concentrations, and the anabolic response of muscle (increase in protein synthesis rate without a change in degradation) was dependent on insulin replacement (Jacob et al. 1996). It would appear, therefore, that the anabolic response of muscle to exogenous $\mathrm{GH}$ is related to independent effects on insulin and IGF-1 secretion or, at least, accumulation in the plasma. In fact, in GH-treated pigs, we found a significant correlation between plasma IGF-1 and muscle $K_{R N A}$ (Fig. 3) rather than FSR. Since the same relationship was shown in Piétrain piglets (see p. 568) it suggests that higher muscularity is related to the activity of the somatotrophic axis.

In addition, it is important to consider that GH induces $\mathrm{GH}$ binding to liver (Chung \& Etherton, 1986), probably through the action of thyroid hormones (TH). The action of $\mathrm{GH}$ on the de-iodination of thyroxine (T4) to triiodothyronine (T3; Kühn et al. 1987; Jørgensen et al. 1992) may have explained the decrease in plasma T4 concentrations (Table 8) also observed by Etherton et al. (1987) and Agergaard et al. (1991) after GH treatment, particularly when dietary energy intake was relatively low (Sève et al. 1993). Support for the implication of $\mathrm{TH}$ in the action of exogenous $\mathrm{GH}$ was recently given by observations on their role in GH-receptor gene expression in the liver of pigs in late fetal life (Duchamp et al. 1996). However, in our GH-treated group of pigs, plasma T4 concentrations were positively correlated with plasma IGF-1 and with muscle $K_{R N A}$, while they were negatively correlated with carcass muscle content. It would seem, therefore, that the re-partitioning and anabolic effects of $\mathrm{GH}$ do not necessarily involve an increase in muscle $K_{R N A}$ associated with plasma IGF-1, but also some consequences of T4 activation into T3. For example, in rats, higher plasma free $\mathrm{T} 3$ concentrations were found to be associated with higher muscle RNA content (Jepson et al. 1988), also observed in GH-treated pigs.

These observations provide a complex picture of the $\mathrm{GH}$ control of muscle protein turnover and growth in which nutrient signalling, obviously involving insulin, would occur in a context of major alterations in the GH-TH relationship. Furthermore, the role of the GH-dependent IGF-binding protein-3 (Coleman \& Etherton, 1991), which may explain variations in plasma IGF-1 concentrations, is still unknown.

\section{THE EFFECT OF PROTEIN QUALITY OR OF INDIVIDUAL AMINO ACID BALANCE ON MUSCLE PROTEIN TURNOVER IN PIGS}

Protein appears to increase growth performance through enhanced whole-body and muscle protein turnover in pigs. It is important to know whether or not this observation extends to situations where protein accretion is stimulated at constant protein supply with simple addition of the limiting amino acid. In relation to whole-body protein synthesis measured by continuous infusion or feeding of tracer amino acids, the evidence regarding the effect of lysine is conflicting. Fuller et al. $(1987 \mathrm{~b})$ concluded that the addition of L-lysine hydrochloride to a lysine-deficient diet did not affect protein synthesis and tended to reduce protein degradation. Consistent with this finding is the decreased energy cost of the additional protein deposition obtained with supplemental lysine $(16.5 \mathrm{~kJ} / \mathrm{g})$ compared with that obtained with additional protein $(31.6 \mathrm{~kJ} / \mathrm{g}$; Fuller et al. $1987 \mathrm{a})$. However, Salter et al. (1990), and recently Roy et al. (1997), measured significant elevations in both whole-body protein synthesis and degradation rates associated with L-lysine hydrochloride addition to a deficient diet. Furthermore, using the flooding-dose technique combined with comparativeslaughter balance experiments, it was recently shown in chickens that, at a given breast muscle tissue mass, the increase in protein accretion associated with supplementation of a lysine-deficient diet resulted from a decrease in protein degradation at constant synthesis 
Table 10. Effect of threonine supplementation of a deficient diet on growth performance and on protein fractional synthesis rate (Ks) in muscle compared with other tissues (From Sève \& Ballèvre, 1991)

\begin{tabular}{lccc}
\hline \hline Dietary threonine : lysine $\ldots$ & 0.45 & 0.72 & $\begin{array}{c}\text { Statistical significance } \\
\text { of difference }\end{array}$ \\
\hline Average daily gain (g/d) & 114 & 136 & $P<0.01$ \\
Muscle Ks $(\% / \mathrm{d}):$ & 12.3 & 10.4 & NS \\
Longissimus & 13.1 & 9.6 & $P<0.01$ \\
Semitendinosus & 11.1 & 9.9 & NS \\
Trapezius & 86.4 & 67.0 & $P<0.05$ \\
Intestine & 66.9 & 75.0 & $P<0.10$ \\
Liver &
\end{tabular}

rate (Tesseraud et al. 1996). Similar results were obtained in fish with the improvement in dietary amino balance (Langar et al. 1993). Also, we have shown in newly-weaned piglets, compared at the same weight, that crystalline L-threonine supplementation of a threoninedeficient diet improved growth performance by decreasing muscle protein FSR while it tended to increase liver protein FSR (Table 10). Together, these data would suggest that improving the balance of a number of essential amino acids will reduce muscle protein turnover rate.

Among limiting amino acids, tryptophan (Trp) was interesting to study since it has been shown to be the limiting amino acid for protein synthesis in the muscle of pigs (Lin et al. 1988) and in the liver of rats (Sidransky et al. 1984). However, since Trp deficiency is invariably associated with a dramatic depression of appetite, a confusion between the energy and Trp effects was very likely. We have confirmed in tube-fed newly-weaned piglets that crystalline L-Trp supplementation of a Trp-deficient diet increased muscle protein FSR (Cortamira et al. 1991; Table 11). Nevertheless, this effect was obtained only at optimal energy intake and appeared to be closely related to a stimulation in the response of plasma insulin concentrations to the meal. Mediation of the Trp effect by insulin was likely since the $K_{R N A}$ rather than the RNA : protein was increased. The insulin response might have been itself mediated through the entero-insular axis, particularly through glucose-dependent insulinotropic polypeptide (GIP), one of the best candidates for an incretin factor, which was shown to respond to oral rather than intravenous $\operatorname{Trp}$ in the rat

Table 11. Effect of tryptophan supplementation of a deficient diet on muscle protein fractional synthesis rate $\mathrm{Ks}$ and plasma insulin concentrations, 2 and $1 \mathrm{~h}$ after feeding respectively, in tube-fed newly-weaned piglets (From Cortamira et al. 1991)

\begin{tabular}{|c|c|c|c|c|}
\hline \multirow{2}{*}{$\begin{array}{l}\text { Feeding rate ... } \\
\text { Tryptophan }(\mathrm{g} / \mathrm{kg}) \ldots\end{array}$} & \multicolumn{2}{|c|}{ Low } & \multicolumn{2}{|c|}{ High } \\
\hline & 1.9 & 2.9 & 1.9 & 2.9 \\
\hline $\begin{array}{l}\text { Muscle } K s(\% / \mathrm{d}) \\
\quad \text { Longissimus } \\
\text { Semitendinosus } \\
\text { Trapezius } \\
\text { Plasma insulin (mU/) }\end{array}$ & $\begin{array}{r}8.5^{\mathrm{a}} \\
7.5^{\mathrm{a}} \\
7.1^{\mathrm{a}} \\
95^{\mathrm{a}}\end{array}$ & $\begin{array}{l}9 \cdot 8^{\mathrm{a}, \mathrm{b}} \\
7 \cdot 9^{\mathrm{a}} \\
7 \cdot 7^{\mathrm{a}, \mathrm{b}} \\
82^{\mathrm{a}}\end{array}$ & $\begin{array}{r}8.9^{\mathrm{a}} \\
7.9^{\mathrm{a}} \\
7.5^{\mathrm{a}} \\
95^{\mathrm{a}}\end{array}$ & $\begin{array}{r}11.7^{\mathrm{b}} \\
9.8^{\mathrm{b}} \\
8.9^{\mathrm{b}} \\
149^{\mathrm{b}}\end{array}$ \\
\hline
\end{tabular}

${ }^{a, b}$ Means in the same horizontal row with unlike superscript letters were significantly different $(P<0.05)$. 
Table 12. Acute effect of tryptophan on glucose tolerance and plasma glucose-dependent insulinotropic polypeptide (GIP) in tube-fed fasting newly-weaned piglets gastrically infused with glucose or glucose plus tryptophan (From Ponter et al. 1994b)

\begin{tabular}{|c|c|c|c|c|}
\hline \multirow{2}{*}{$\begin{array}{l}\text { Diet... } \\
\text { Gastric infusion... }\end{array}$} & \multicolumn{2}{|c|}{ Tryptophan-deficient } & \multicolumn{2}{|c|}{ Tryptophan-adequate } \\
\hline & Glucose & Glucose + tryptophan & Glucose & Glucose + tryptophan \\
\hline \multicolumn{5}{|c|}{$\begin{array}{l}\text { Integrated mean concentrations } \\
\text { in plasma at } 0-180 \mathrm{~min} \text {. }\end{array}$} \\
\hline Glucose $(\mathrm{mmol} / \mathrm{l})$ & $6.69^{\mathrm{a}}$ & $5 \cdot 70^{\mathrm{b}}$ & $6.49^{\mathrm{a}}$ & $5 \cdot 93^{\mathrm{b}}$ \\
\hline $\operatorname{GIP}(\mu \mathrm{g} / \mathrm{l})$ & $2 \cdot 28^{\mathrm{b}}$ & $2 \cdot 95^{\mathrm{a}}$ & $2 \cdot 12^{\mathrm{b}}$ & $3.46^{\mathrm{a}}$ \\
\hline
\end{tabular}

${ }^{\mathrm{a}, \mathrm{b}}$ Means in the same horizontal row with unlike superscript letters were significantly different $(P<0 \cdot 05)$.

(Tsiolakis \& Marks, 1984). On the other hand, we found in later experiments that more severe Trp deficiency (in tube-fed piglets) could be associated with insulin resistance. This was demonstrated by the accumulation of both glucose and insulin in the plasma of pigs submitted to an oral glucose tolerance test and was more apparent in pigs fed on a fat-rich diet (Ponter et al. 1991). Parallel to this, growth performance as well as muscle protein FSR were reduced to a greater extent by dietary Trp deficiency in pigs fed on a fat-rich diet than in those fed on a carbohydrate-rich diet (Ponter et al. 1994a). The effect of Trp on glucose utilization was not accompanied by variation in plasma insulin levels when it was studied acutely through the addition of Trp to glucose in the course of an oral glucose tolerance test (Ponter et al. 1994b; Table 12). Furthermore, it was clearly associated with a significant rise in plasma GIP concentrations. Whitcomb et al. (1984) have reported finding GIP receptors in various muscle groups in the rat. The finding of these receptors was suggested to be related to the discovery of a strong correlation between peripheral glucose utilization and the increase in GIP after a meal in diabetics (Osei et al. 1986) and to an exercise-induced improvement in glucose utilization in obese children associated with an increase in GIP (Kahle et al. 1986). There is increasing evidence for peripheral actions of gastrointestinal components of the entero-insular axis such as GIP or glucagon-like polypeptide-1 (Egan et al. 1994; Knapper et al. 1995). These polypeptides, therefore, could be signals not only for insulin secretion but also for tissue sensitivity to insulin. However, definitive evidence that muscle protein synthesis may be acutely stimulated through this pathway by Trp, or other amino acids, is still lacking.

\section{CONCLUSIONS}

The somatotrophic axis is believed to regulate muscle protein turnover in the long term (Fig. 4). TH could play a role in stimulating the synthesis of GH receptors, at least in the liver, which would enhance IGF-1 synthesis and its endocrine action on peripheral tissues. The effect of IGF-1 on muscle protein synthesis is well documented, but the role of IGFbinding protein in the availability of the molecule at the receptor level still deserves attention. On the other hand, there is transcription of the GH receptor and expression of muscle GH-binding activity at all stages of growth, including fetal life, in pigs (Schnoebelen-Combes et al. 1996). This observation raises the question of possible local IGF-1 expression and of its autocrine or paracrine action on muscle protein synthesis. The extent to which the observation of rapid effects of nutrients on the expression of the IGF-1 gene in the muscle questions the hypothesis of a strictly long-term regulation of muscle protein metabolism through the somatrophic axis, should be evaluated in pigs. 


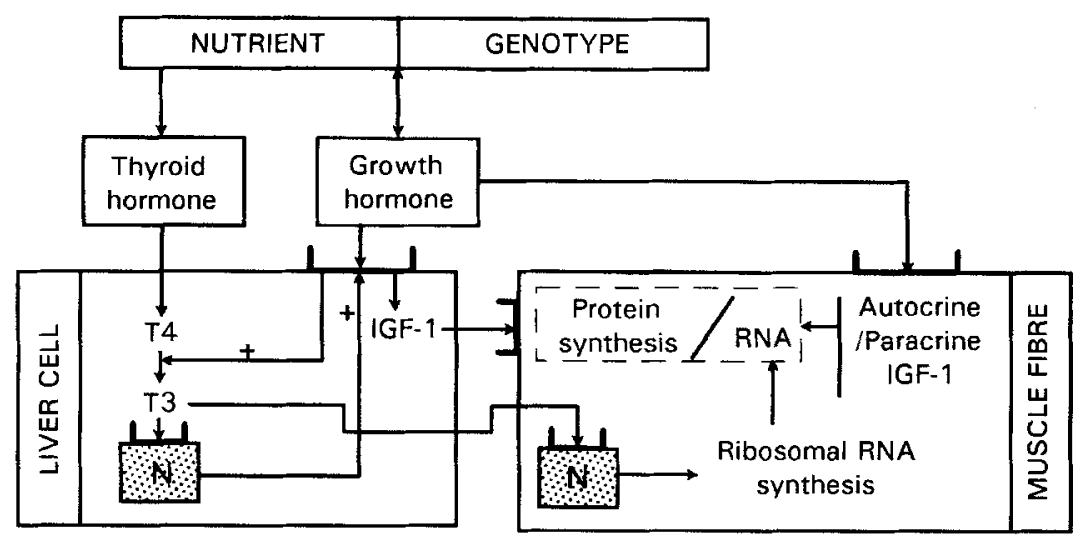

Fig. 4. Long-term control of muscle protein turnover. $\uparrow$, The genotype $\times$ insulin-induced hypoglycaemia interaction for endogenous growth hormone $(\mathrm{GH})$ secretion. IGF-1, insulin-like growth factor-1; T4, thyroxine; T3, triiodothyronine. (From Bonneau, 1993).

Nevertheless, insulin seems to be the main hormone involved in the short-term control of muscle protein synthesis and turnover by nutrients in pigs, as in other young animals (Fig. 5). The first reason for this is the involvement of nutrients, particularly the synergy of glucose and amino acids, in the stimulation of insulin secretion. Furthermore, although apparently independent of insulin, the direct effect of the aminoacidaemia, on muscle protein synthesis probably results from the action of specific amino acids (branched-chain amino acids), or of their metabolites, on tissue sensitivity to insulin action. The enhancement of the insulin response through enteral administration of nutrients was confirmed recently in pigs (Sève et al. 1997), providing strong support for the concept of the entero-insular axis in this species as in human subjects and, consequently, for the hypothesis of an acute regulation of muscle protein synthesis associated with intestinal nutrient absorption at each meal. This theory would be further strengthened if signals from the gastrointestinal tract involved not only the insulin post-receptor cascade controlling glucose, but also that controlling amino acid utilization (Marshall et al. 1991), as suggested by studies on Trp.

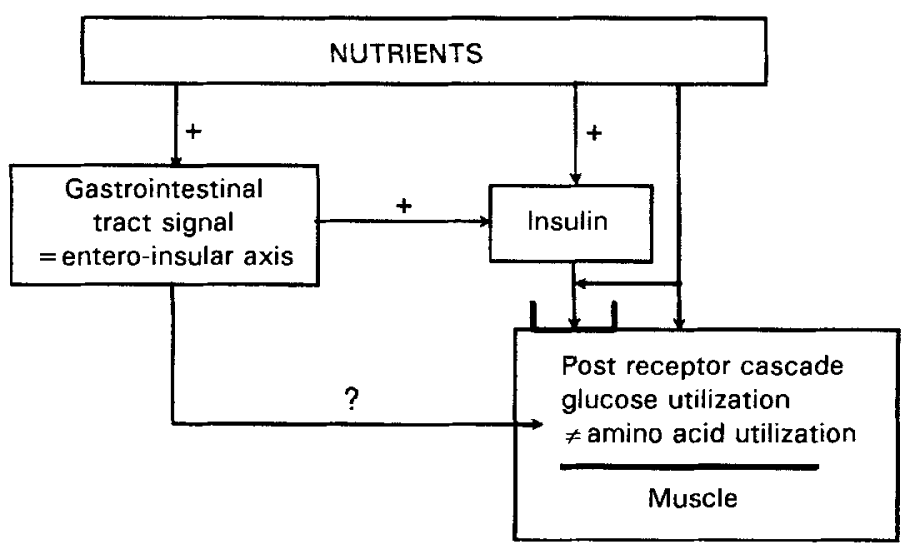

Fig. 5. Short-term control of muscle protein turnover. لـ, Receptor; +, stimulation. 


\section{REFERENCES}

Adeola, O., Young, L. G., McBride, B. W. \& Ball, R. O. (1989). In vitro $\mathrm{Na}^{+}, \mathrm{K}^{+}$-ATPase (EC 3.6.1.3)dependent respiration and protein synthesis in skeletal muscle of pigs fed at three dietary protein levels. British Journal of Nutrition 61, 453-465.

Agergaard, N., Oksbjerg, N. \& Sorensen, M. T. (1991). Influence of growth hormone on homeostasis in finishing pigs. In Protein Metabolism and Nutrition. European Association for Animal Production Publication no. 59, vol. 2, pp. 194-197 [B. O. Eggum, S. Boisen, C. Borsting, A. Danfaer and T. Hvelplund, editors]. Foulum, Denmark: National Institute of Animal Science.

Aoyagi, Y., Tasaki, I., Okomura, J. \& Muramatsu, T. (1988). Energy cost of whole-body protein synthesis measured in vivo in chicks. Comparative Biochemistry and Physiology 91A, 765-768.

Baillie, A. \& Garlick, P. J. (1991a). Attenuated responses of muscle protein synthesis to fasting and insulin in adult female rats. American Journal of Physiology 262, E1-E5.

Baillie, A. \& Garlick, P. J. (1991b). Responses of protein synthesis in different skeletal muscles to fasting and insulin in rats. American Journal of Physiology 260, E1-E5.

Bennet, W. M., Connacher, A. A., Scrimgeour, C. M., Smith, K. \& Rennie, M. J. (1990). The effect of amino acid infusion on leg protein turnover assessed by L- $\left[{ }^{15} \mathrm{~N}\right]$ phenylalanine and L- $\left[{ }^{13} \mathrm{C}\right]$ leucine exchange. European Journal of Clinical Nutrition 20,37-46.

Bonneau, M. (1993). Growth hormone response to GRF and insulin-induced hypoglycemia in Yorkshire and Meishan pigs. American Journal of Physiology 264, E54-E59.

Burrin, D. G., Davis, T. A., Ebner, S., Shoknecht, P. A., Fiorotto, M. L., Reeds, P. J. \& McAvoy, S. (1995). Nutrient-independent and nutrient-dependent factors stimulate protein synthesis in colostrum-fed newborn pigs. Pediatric Research 37, 593-599.

Burrin, D. G., Shulman, R. J., Reeds, P. J., Davis, T. A. \& Gravitt, K. R. (1992). Porcine colostrum and milk stimulate visceral organ and skeletal muscle protein synthesis in neonatal piglets. Journal of Nutrition 122 , $1205-1213$.

Chung, C. S. \& Etherton, T. D. (1986). Characterization of porcine growth hormone (pGH) binding to porcine liver microsomes: Chronic administration of pGH induces pGH binding. Endocrinology 119, 780-786.

Coleman, M. E. \& Etherton, T. D. (1991). Effects of exogenous porcine growth hormone on serum insulin-like growth factor-binding proteins in growing pigs. Journal of Endocrinology 128, 175-180.

Cortamira, N. O., Sève, B., Lebreton, Y. \& Ganier, P. (1991). Effect of dietary tryptophan on muscle, liver and whole-body protein synthesis in weaned piglets: relationship to plasma insulin. British Joumal of Nutrition 66, 423-435.

Davis, T., Burrin, D. G., Fiorotto, M. L. \& Nguyen, H. V. (1996). Protein synthesis in skeletal muscle and jejunum is more responsive to feeding in 7- than in 26-day-old pigs. American Journal of Physiology 270, E802-E809.

Duchamp, C., Burton, K. A., Herpin, P. \& Dauncey, M. J. (1996). Perinatal ontogeny of porcine growth hormone receptor gene expression is modulated by thyroid status. European Journal of Endocrinology 134, 524-531.

Egan, J. M., Montrose-Rafizadeh, C., Wang, Y., Bernier, M. \& Roth, J. (1994). Glucagon-like peptide-1(7-36) amide (GLP-1) enhances insulin stimulated glucose metabolism in 3T3-L1 adipocytes: One of several potential extrapancreatic sites of GLP-1 action. Endocrinology 135, 2070-2075.

Etherton, T. D., Wiggins, J. P., Evock, C. M., Chung, C. S., Rebhun, J. F., Walton, P. E. \& Steele, N. C. (1987). Stimulation of pig growth performance by porcine growth hormone: determination of the dose-response relationship. Journal of Animal Science 64, 433-443.

Fluckey, J., Vary, T. C., Jefferson, L. S. \& Farrell, P. A. (1996). Augmented insulin action on rates of protein synthesis after exercise in rats. American Journal of Physiology 270, E313-E319.

Fuller, M. F., Cadenhead, A., Mollison, G. \& Sève, B. (1987a). Effects of the amount and quality of dietary protein on nitrogen metabolism and heat production in growing pigs. British Journal of Nutrition 58, 277-285.

Fuller, M. F. \& Garthwaite, P. (1993). The form of response of body protein accretion to dietary amino acid supply. Joumal of Nutrition 123, 957-963.

Fuller, M. F., Reeds, P. J., Cadenhead, A., Sève, B. \& Preston, T. (1987b). Effects of the amount and quality of dietary protein on nitrogen metabolism and protein turnover of pigs. British Journal of Nutrition 58, 287-300.

Fuller, M. F., Weekes, T. E. C., Cadenhead, A. \& Bruce, J. B. (1977). The protein-sparing effect of carbohydrate. 2. The role of insulin. British Journal of Nutrition 38, 489-496.

Gahl, M. J., Crenshaw, T. D. \& Benevenga, N. J. (1994). Diminishing-returns in weight, nitrogen, and lysine gain of pigs fed six levels of lysine from three supplemental sources. Journal of Animal Science 72, 31773187.

Garlick, P. J., Fern, M. \& Preedy, V. R. (1983). The effect of insulin infusion and food intake on muscle protein synthesis in postabsorptive rats. Biochemical Journal 210, 669-676.

Garlick, P. J. \& Grant, I. (1988). Amino acid infusion increases the sensitivity of muscle protein synthesis in vivo to insulin. Biochemical Journal 254, 579-584.

Garlick, P. J., McNurlan, M. A. \& Preedy, V. R. (1980). A rapid and convenient technique for measuring the rate of protein synthesis in tissues by injection of $\left[{ }^{3} \mathrm{H}\right]$ phenylalanine. Biochemical Journal 192, 719-723. 
Grant, A. L., Helferich, W. G., Kramer, S. A., Merkal, R. A. \& Bergen, W. G. (1991). Administration of growth hormone to pigs alters the relative amount of insulin-like growth factor-I mRNA in liver and skeletal muscle. Journal of Endocrinology 130, 331-338.

Grizard, J., Dardevet, D., Papet, I., Mosoni, L., Patureau-Mirand, P., Attaix, D., Tauveron, I., Bonin, D. \& Arnal, M. (1995). Nutrient regulation of skeletal muscle protein metabolism in animals. The involvement of hormones and substrates. Nutrition Research Reviews 8, 67-91.

Jacob, R., Hu, X., Niederstock, D., Hasan, S., McNulty, P. H., Sherwin, R. S. \& Young, L. H. (1996). IGF-I stimulation of muscle protein synthesis in the awake rat: permissive role of insulin and amino acids. American Journal of Physiology 270, E60-E66.

Jepson, M. M., Bates, P. C. \& Millward, D. J. (1988). The role of insulin and thyroid hormones in the regulation of muscle growth and protein turnover in response to dietary protein in the rat. British Journal of Nutrition 59, $397-415$.

Jørgensen, J. O. L., Møller, J., Skakkeboek, N. E., Weeke, J. \& Christiansen, J. S. (1992). Thyroid function during growth hormone therapy. Hormone Research 38, Suppl. 1, 63-67.

Kahle, E. B., O'Dorisio, T. M., Walker, R. B., Eisenman, P. A., Reiser, S., Cataland, S. \& Zipf, W. B. (1986). Exercise adaptation responses for gastric inhibitory polypeptide (GIP) and insulin in obese children. Possible extra-pancreatic effects. Diabetes 35, 579.

Knapper, J. M. E., Puddicombe, S. M., Morgan, L. M. \& Fletcher, J. M. (1995). Investigations into the actions of glucose-dependent insulinotropic polypeptide and glucagon-like peptide-1(7-36) amide on lipoprotein lipase activity in explants of rats adipose tissue. Journal of Nutrition 125, 183-188.

Kühn, E. R., Verheyen, G., Chiasson, R. B., Huts, C., Huybrechts, L., van den Steen, P. \& Decuypere, E. (1987). Growth hormone stimulates the peripheral conversion of thyroxine into triiodothyronine by increasing the liver $5^{\prime}$ monodeiodinase activity in the fasted and normal fed chicken. Hormone and Metabolic Research 19, 304-308.

Langar, H., Guillaume, J., Metailler, R. \& Fauconneau, B. (1993). Augmentation of protein synthesis and degradation by poor amino acid balance in European sea bass (Dicentrarchus Labrax). Journal of Nutrition 123, 1754-1761.

Lin, F. D., Smith, T. K. \& Bayley, H. S. (1988). A role for tryptophan in regulation of protein synthesis in porcine muscle. Journal of Nutrition 118, 445-449.

Marshall, S., Garvey, W. T. \& Traxinger, R. R. (1991). New insights into the metabolic regulation of insulin action and insulin resistance: rôle of glucose and amino acids. FASEB Journal 5, 3031-3036.

Noblet, J., Fortune, H., Dubois, S. \& Henry, Y. (1989). Nouvelles Bases d'Estimation des Teneurs en Énergie Digestible, Métabolisable et Nette des Aliments pour le Porc (New Basis for Estimation of Digestible, Metabolizable and Net Energy in Diets for Pigs). Paris: INRA.

Osei, K., Falko, J. M., O’Dorisio, T. M., Fields, P. G. \& Bossetti, B. (1986). Gastric inhibitory polypeptide responses and glucose turnover rates after natural meals in type II diabetic patients. Journal of Clinical Endocrinology and Metabolism 62, 325-330.

Ostaszewski, P. \& Nissen, S. (1988). Effect of hyperglucagonemia on whole-body leucine metabolism in immature pigs before and during a meal. American Journal of Physiology 254, E372-E377.

Ponter, A. A., Cortamira, N. O., Sève, B., Salter, D. N. \& Morgan, L. M. (1994a). The effects of energy source and tryptophan on the rate of protein synthesis and on hormones of the entero-insular axis in the piglet. British Journal of Nutrition 71, 661-674.

Ponter, A. A., Sève, B., Cortamira, N. O., Salter, D. N. \& Morgan, L. M. (1991). The effects of dietary energy source and tryptophan on hormones of the entero-insular axis and glucose in the early weaned pig after intragastric infusion of glucose. Proceedings of the Nutrition Society 50, 227A.

Ponter, A. A., Sève, B. \& Morgan, L. M. (1994b). Intragastric tryptophan reduces glycemia after glucose, possibly via glucose-mediated insulinotropic polypeptide (GIP) in early weaned piglets. Joumal of Nutrition 124, 259-267.

Preedy, V. R. \& Garlick, P. J. (1986). The response of muscle protein synthesis to nutrient intake in postabsorbtive rats: The role of insulin and amino acids. Bioscience Reports 6, 177-183.

Reeds, P. J., Cadenhead, A., Fuller, M. F., Lobley, G. E. \& McDonald, J. D. (1980). Protein turnover in growing pigs. Effects of age and food intake. British Journal of Nutrition 43, 445-455.

Reeds, P. J. \& Fuller, M. F. (1983). Nutrient intake and protein turnover. Proceedings of the Nutrition Society 42, 463-471.

Reeds, P. J., Fuller, M. F., Cadenhead, A., Lobley, G. E. \& McDonald, J. D. (1981). Effects of changes in the intakes of protein and non-protein energy on whole-body protein turnover in growing pigs. British Journal of Nutrition 45, 539-546.

Reeds, P. J., Fuller, M. F. \& Nicholson, B. A. (1985). Metabolic basis of energy expenditure with particular reference to protein. In Substrate and Energy Metabolism in Man, pp. 46-57 [J. S. Garrow and W. Halliday, editors]. London: John Libbey \& Co.

Roy, N., Lapierre, H. \& Bernier, J. F. (1997). Effect of lysine deficiency on whole body protein metabolism in growing pigs. Proceedings of the Nutrition Society 56, 176A.

Salter, D. N., Montgomery, A. I., Hudson, A., Quelch, D. B. \& Elliot, R. J. (1990). Lysine requirements and whole-body protein turnover in growing pigs. British Journal of Nutrition 63, 503-513. 
Schnoebelen-Combes, S., Louveau, I., Postel-Vinay, M.-C. \& Bonneau, M. (1996). Ontogeny of GH receptor and GH-binding protein in the pig. Journal of Endocrinology 148, 249-255.

Sève, B. \& Ballèvre, O. (1991). Approches métaboliques du besoin en acides aminés chez le porc en croissance (Metabolic approach to the amino acid requirements of the pig for growth). Joumées de la Recherche Porcine en France 23, 91-110.

Sève, B., Ballevre, O., Ganier, P., Noblet, J., Prugnaud, J. \& Obled, C. (1993). Recombinant porcine somatotropin and dietary protein enhance protein synthesis in growing pigs. Journal of Nutrition 123, 529540.

Sève, B., Lebreton, Y., Peiniau, P. \& Ganier, P. (1987). Protein synthesis as influenced by weaning in the young pig. In Protein Metabolism and Nutrition, European Association for Animal Production Publication no. 35 [J. Lehman, editor]. Rostock: Wilhelm-Pieck Universität.

Sève, B., Reeds, P. J., Fuller, M. F., Cadenhead, A. \& Hay, S. M. (1986). Protein synthesis and retention in some tissues of the young pig as influenced by dietary protein intake after early weaning. Possible connection to the energy metabolism. Reproduction Nutrition Développement 26, 849-861.

Sève, B., Ronat, P., Hess, V., Matte, J. J. \& Ponter, A. A. (1997). Evidence for the entero-insular axis in weanling piglets. 7th Symposium on Digestive Physiology in Pigs, St-Malo, France. (In the Press).

Sidransky, H., Murty, C. N. \& Verney, E. (1984). Nutritional control of protein synthesis studies relating to tryptophan-induced stimulation of nucleocytoplasmic translocation of mRNA in rat liver. American Journal of Pathology 117, 298-309.

Svansberg, E., Zacharisson, H., Ohlsson, C., Britt-Marie, I. \& Lunholm, K. G. (1996). Role of insulin and IGF-1 in activation of muscle protein synthesis after oral feeding. American Journal of Physiology 270, E614-E620.

Tesseraud, S., Peresson, R., Lopes, J. \& Chagneau, A. M. (1996). Dietary lysine deficiency greatly affects muscle and liver protein synthesis in growing chickens. British Journal of Nutrition 75, 853-865.

Tsiolakis, D. \& Marks, V. (1984). The differential effect of intragastric and intravenous tryptophan on plasma glucose, insulin, glucagon, GLI and GIP in the fasted rat. Hormone and Metabolic Research 16, 226-229.

Waterlow, J. C., Garlick, P. J. \& Millward, D. J. (1978). Protein Turnover in Mammalian Tissues and in the Whole Body. Amsterdam: North-Holland.

Watt, P. W., Corbett, M. E. \& Rennie, M. J. (1992). Stimulation of protein synthesis in pig skeletal muscle by infusion of amino acids during constant insulin availability. American Journal of Physiology 263, E453-E460.

Whitcomb, D. C., O'Dorisio, T. M., Nishikawa, M. T., Shetzline, M. \& Cataland, S. (1984). Identification of target organs for gastric inhibitory polypeptide (GIP) with a new in vivo radioreceptor assay. Digestive Diseases and Sciences 29, 95A. 